\title{
Fortification of fried potato chips with antioxidant vitamins to enhance their nutritional value and storage ability
}

\author{
By Samah Said Mahmoud Allam and Fyka Edress El-Sayed
}

\author{
Oils and Fats Research Department, Food Technology Research Institute, Agriculture Research \\ Center, 9 Gamaa St., Giza, Egypt. E-mail: -samahallam@yahoo.com
}

\section{RESUMEN}

Mejora del valor nutricional y tiempo de almacenaje de patatas fritas en presencia de vitaminas con actividad antioxidante.

Mediante la adición de antioxidantes sintéticos y naturales, como TBHQ, retinil palmitato y ascorbil palmitato, es posible aumentar la estabilidad de aceites para la fritura comercial. Los resultados indican que TBHQ, seguido de retinil palmitato y ascorbil palmitato, en este orden, es el mejor para retrasar el deterioro de las condiciones para la fritura, $24 \mathrm{~h}$ a $180^{\circ} \mathrm{C}$, de patatas fritas cuando se compara con un control sin aditivos.

Se tomaron muestras de patatas fritas en aceites con y $\sin$ vitaminas antioxidantes durante las primeras 8 horas de fritura, y se dividieron en tres porciones para someterlas a diferentes tratamientos: 1) sin aditivos (muestras control de patatas fritas con aceite control o con aceite que contenía TBHQ, retinil palmitato o ascorbil palmitato; 2) enriquecimiento de las cuatro muestras anteriores con vitamina $\mathrm{E}$ (tocoferol) mediante la inmersión de las patatas fritas en aceite con $0,1 \%$ tocoferol; y 3 ) enriquecimiento de las muestras anteriores con vitamina $\mathrm{C}$ mediante la dispersión de una mezcla de sal fina y ascorbil palmitato sobre la superficie de las patatas fritas y agitación de las mismas en el interior de paquetes. Las muestras controles y enriquecidas se empaquetaron en paquetes de aluminio y fueron guardadas en un horno eléctrico a $63 \pm 1^{\circ} \mathrm{C}$

La estabilidad de las patatas fritas a $63 \pm 1^{\circ} \mathrm{C}$ aumentó en presencia de vitamina $E$ y de vitamina $C$ antes del empaquetamiento y almacenamiento a esa temperatura.

Las patatas fritas con aceite enriquecido en vitaminas $A, C$ y TBHQ fueron las que mejor se conservaron a $63^{\circ} \mathrm{C}$; este efecto se prolongó mediante la adición de vitaminas $\mathrm{E}$ ó $\mathrm{C}$ después del proceso de fritura y antes de su almacenamiento a $63^{\circ} \mathrm{C}$ en paquetes de aluminio. Estos resultados demuestran el efecto sinérgico de vitaminas con actividad antioxidante que pueden actuar de manera independiente o complementaria a TBHQ, el cual además las protege en estas condiciones termo-oxidativas.

PALABRAS-CLAVE: Patatas fritas-Antioxidantes-Vitaminas.

\section{SUMMARY}

Fortification of fried potato chips with antioxidant vitamins to enhance their nutritional value and storage ability.

The frying shelf life of commercial frying oil was increased by the addition of synthetic and natural antioxidants, e.g. TBHQ, retinyl palmitate and ascorbyl palmitate (antioxidant vitamins). The results revealed that TBHQ had the best effect in retarding the deteriorative effect of frying conditions throughout $24 \mathrm{~h}$ of frying potato chips at $180 \pm 10^{\circ} \mathrm{C}$ followed by the effect of retinyl palmitate and the effect of ascorbyl palmitate compared to the control without any additives.

Fried potato chips in oils either with or without antioxidant were collected during the first $8 \mathrm{~h}$ of frying, divided into 3 main portions each portion had different treatment; 1 ) without any additives (control samples for fried potatoes resulting from the control oil or from oil containing TBHQ or containing retinyl or ascorbyl palmitate. 2) fortification of the above 4 samples with vitamin $E$ (tocopherol) by dipping each of the resulting samples from the four frying trials separately in oil containing $0.1 \%$ tocopherol. 3) fortification of each of the above mentioned samples with vitamin $C$ by dispersing the mixture of fine salt and ascorbyl palmitate on the fried chips' surface and vigorous shaking in bags. The control samples and fortified samples were packed in aluminum bags and stored in an electric oven at $63 \pm$ $1^{\circ} \mathrm{C}$.

The storage ability of fried potatoes at $63 \pm 1^{\circ} \mathrm{C}$ was increased by the fortification with antioxidant vitamins either with vitamin $\mathrm{E}$ (tocopherol) or with vitamin C (ascorbyl palmitate) before packaging and storing at $63 \pm 1^{\circ} \mathrm{C}$. The results indicated that potatoes fried in oil without any additives (control) had the lowest storage stability and that it was increased by the fortification with antioxidant vitamins, $\mathrm{C}$ or $\mathrm{E}$.

Potato chips fortified with vitamins $A$ or $C$ by frying in oil containing retinyl palmitate or ascorbyl palmitate and also in oil containing TBHQ had better storage ability at $63^{\circ} \mathrm{C}$ and this was also prolonged by the addition of vitamin $\mathrm{E}$ or $\mathrm{C}$ after the frying processes and before storing at $63^{\circ} \mathrm{C}$ in aluminium bags. This demonstrated the synergistic effect of the antioxidant vitamins which work either alone or complementary to each other along with the protective effect of the phenolic antioxidant (TBHQ) which protected these vitamins by supporting their antioxidant function.

KEY-WORDS: Antioxidants-Potato chips-Vitamins.

\section{INTRODUCTION}

Shelf life is a major consideration in developing, producing, and marketing many food products. Consumers desire products that maintain a fresh appearance, odour, and flavour for as long as possible, and a longer shelf life reduces costs for the producer and, ultimately, for the consumer.

Potato chips are generally consumed a few weeks after preparation. The high (up to $40 \%$ ) lipid content of the chips, their high surface-to-volume ratio and packaging in the presence of oxygen result in oxidative deterioration of the product.

One of the factors that contribute significantly to the quality of the final product is the frying medium. Degradation of the frying medium, which is absorbed into the chips, depends strongly on the presence of unsaturated fatty acids. Vegetable oils that have a high content of polyunsaturated fatty acids form a 
higher ratio of oxidized products during frying compared with oils that have high oleic and saturated fatty acids content, e.g., palm olein.

Lipid oxidation is a major deteriorative reaction in frying oils and fried foods, and often results in a significant decrease in quality. In addition, lipid oxidation can lead to changes in functional, sensory, and nutritive values and even the safety of fried food. Generally, these changes reduce consumer acceptance of oxidized products (Velasco et al., 2002). Lipid oxidation products, such as free radicals, peroxides, aldehydes, and ketones are harmful to human health (Byrd, 2001). Many of the degenerative diseases of aging including cancer, cardiovascular disease, cataracts, and other diseases result from long-term exposure to destructive chemical entities in the body called free radicals (Hercberg et al., 1998). Substances, which are capable of quenching or stabilizing free radicals, are called antioxidants (Elliott, 1999). Antioxidants are usually added to fats, oils, and foods containing fat in order to inhibit the development of off-flavours arising from the oxidation of unsaturated fatty acids. However, the commercial use of synthetic antioxidants is strictly controlled and increasing consumer awareness of food additives and safety has promoted increased interest in the use of natural antioxidants, e.g., ascorbic acid and tocopherol (Byrd, 2001) as alternatives to synthetic compounds. Accordingly, many studies on the antioxidant activity of medicinal and edible plants and their application to food preservation have been conducted (Lolos et al., 1999; Park et al., 2002; Samah and Mohamed, 2002).

Several antioxidants have been used to retard the deterioration of fried oils. Among the commonly applied antioxidants, tertiary butylhydroquinone (TBHQ) gave adequate protection, whereas butylated hydroxyanisole (BHA) and butylated hydroxytoluene (BHT) were relatively ineffective (Tsaknis et al., 2002). An extensive loss due to decomposition or evaporation (steam volatility) of $\mathrm{BHA}$ and BHT was observed at the elevated temperature of the frying process (Gordon and Kourimska, 1995). TBHQ also underwent decomposition. Nevertheless, TBHQ was effective in extending the shelf life of the products, because the breakdown products may also be effective antioxidants. In a study of TBHQ photo-oxidation, one of the derivatives produced showed strong antioxidant activity (Lolos et al., 1999). Ascorbyl palmitate (AP), a fat-soluble ester of palmitic and ascorbic acids, could be used in oils or oil foods. AP is a substance that is generally recognized as safe (GRAS) with no specific limitation or restriction. Consumer ingestion of this antioxidant would pose no health hazard because its metabolic breakdown yields ascorbic and palmitic acids, both normal metabolites (Gow et al., 1985; Gordon and Kourisma, 1995; Lee et al., 1997; Abdel-Rahman, 2001). AP added into oils before frying retarded thermal degradation during frying and peroxide formation after the frying operation (Lolos et al., 1999).

The use of natural compounds to prevent degradation during frying has also been suggested by several researchers (Tian and White, 1994; Gordon and Kourisma, 1995; Yanishlieva et al., 1997).

Certain vitamins act as antioxidants, protecting cells from free radical-induced damage (Block and Langseth, 1994; Anon, 1996; Camire and Kantor, 1999). Vitamins C, E and $\beta$-carotene (a pro-vitamin that converts in the body to vitamin $A$ as needed) have antioxidant properties that make them ideal for use in nutraceutical products and they are referred to as the antioxidant vitamins (Elliott, 1999). Vitamin A can be characterized as a long chain alcohol. It is sensitive to oxidation in the presence of oxygen, light, heat, and catalysts of oxidation. The ester forms, such as retinyl palmitate (RP) and retinyl acetate, are more stable than retinol; therefore, they are used for food fortification (Suknark et al., 2001). They all work both individually and synergistically to prevent or delay oxidative reactions that lead to degenerative diseases over time (Hercberg et al., 1998).

Antioxidant vitamins protect the body against certain types of cancer, cardiovascular disease, cataracts, arthritis, diabetes, and Alzheimer's disease. The antioxidant vitamins are GRAS, have a substantial record of safety (Vatassery et al., 1989; Farriol et al., 1994; Ocke et al., 1995; Salonen et al., 1995; Evans and Morris, 1996; Hennekens, 1996; Coben et al., 1997; Drachman and Leber, 1997; Jacques et al., 1997; Plotinick et al., 1997; Elliott, 1999).

This study was conducted to increase the shelf life of frying oils by adding antioxidants and to compare the effects of natural antioxidants such as, retinyl palmitate [RP] (vitamin A), ascorbyl palmitate [AP] (vitamin C) to the effects of the synthetic antioxidant (TBHQ). The main goal was to increase the shelf life of the final product (potato chips) by adding natural antioxidants in order to increase its storage ability. We used "antioxidant vitamins" to fortify the final products either, by frying the potatoes in oils containing vitamin $\mathrm{A}$ or $\mathrm{C}$; or adding vitamin $\mathrm{E}$ or $\mathrm{C}$ after frying. The later was conducted by two fortification trials: dipping in oil containing vitamin $\mathrm{E}$ or by dispersing the mixture of salt and vitamin $\mathrm{C}$ on the chips' surface.

\section{MATERIALS AND METHODS}

\section{Materials:}

Potatoes were purchased from a local market, washed, peeled, cut into chips using a machine 
cutter to prepare thin slices of potatoes, and soaked in water until frying. Commercial olein oil, purchased locally, was used as the frying medium. TBHQ, obtained from Fluka, Switzerland, was used as a synthetic antioxidant and $200 \mathrm{ppm}$ were added to the oil before the frying procedure. Retinyl palmitate (vitamin A) [RP] purchased from Sigma Chemical Co., U.S.A., and ascorbyl palmitate (vitamin C) [AP] obtained from Dominco Inc. Co., Denmark, were used as natural antioxidants and added to a concentration of $1,000 \mathrm{ppm}$ to the oil before the frying procedure. Mixed tocopherol [Toc] (mainly $\alpha$-tocopherol; vitamin E) obtained from Dominco Inc. Co., Denmark, was used to fortify the fried potato chips by dipping them in oil containing $0.1 \%$ tocopherol (1,000 ppm). A control oil without any additives was also used for frying potato chips.

\section{Experimental procedures:}

The frying experiment was conducted in four individual trials: oil containing $0.02 \% \mathrm{TBHQ}$, oil containing $0.1 \%$ retinyl palmitate, oil containing $0.1 \%$ ascorbyl palmitate, and a control oil without any additives. Each frying procedure was conducted within a few minutes of the sliced potatoes being prepared using a laboratory fryer filled with $2.5 \mathrm{~kg}$ of oil and capable of maintaining its temperature within a range of $\pm 10^{\circ} \mathrm{C}$. After the removal of the excess water with a filter paper, batches of $100 \mathrm{~g}$ of sliced potatoes were fried successively for 3 min every 15 min in the four tested oils. The initial frying temperature was set at $18010^{\circ} \mathrm{C}$. The temperature decreased by approximately $17^{\circ} \mathrm{C}$ within $1.5 \mathrm{~min}$ of the addition of the sliced potatoes and increased by $5^{\circ} \mathrm{C}$ until the end of frying which continued for 8 $\mathrm{h} /$ day, oil was not topped off during the $24 \mathrm{~h}$ of frying in all of the tested oils. Samples of frying oils were taken after the daily frying operation and kept at $-20^{\circ} \mathrm{C}$ until further analysis.

The chips from the separate batches fried in the same oil were collected throughout the first $8 \mathrm{~h}$ of frying (the first day of frying in all tested oils), mixed together and an appropriate amount $(\sim 200 \mathrm{~g})$ was tested immediately for analysis of the absorbed oil. The remaining chips were separated into three portions, two of them treated with two different fortification treatments with different antioxidant vitamins e.g., vitamin $E$, tocopherol and vitamin $C$, ascorbyl palmitate and the third portion was kept without any treatment as the control sample. The fortified chips and the control chips were each separated into eight portions ( 200 g) and put into bags (aluminium-sealed bags). The bags were kept in an electric oven at $63 \pm 1{ }^{\circ} \mathrm{C}$ for 8 days, until opened for the analysis of the absorbed oils. Samples of each treatment and the control were withdrawn daily (every $24 \mathrm{~h}$ ) throughout the 8 day storage period. All experiments were run in duplicate and the presented results are the average of two trials.

\section{Fortification of antioxidant vitamins:}

In the first series of experiments with antioxidants, different antioxidants were added separately to the oil in the three individual trials: $200 \mathrm{ppm}$ of TBHQ $(0.5$ g) was added to the commercial olein oil before frying and mixed thoroughly, $1000 \mathrm{ppm}$ of retinyl palmitate $(2.5 \mathrm{~g})$ was dissolved in frying oil before the frying procedure, and 1000 ppm of ascorbyl palmitate $(2.5 \mathrm{~g})$ was also dissolved in oil used for frying chips before starting the frying procedure.

In the second series of experiments with antioxidant vitamins, $1000 \mathrm{ppm}$ of vitamin $E$ (tocopherol) dissolved in olein oil (the same tested oil used for the frying procedure) $(0.1 \%)$ was applied by dipping the chips into the vitamin $\mathrm{E}$ olein oil after the frying process. In the third series of experiments with antioxidant vitamins, ascorbyl palmitate (vitamin C), a fine powder, was mixed with salt and added to the fried chips after frying in the four tested oils (control oil, without any additives, oil containing $0.02 \%$ $\mathrm{TBHQ}$, oil containing $0.1 \%$ retinyl palmitate and the forth oil which contain $0.1 \%$ ascorbyl palmitate). The mixture of salt with vitamin $\mathrm{C}$ was finely dispersed on the chips' surface and mixed well by vigorous shaking in a bag. The quantities of additives on the chips were salt, $10 \mathrm{~g} / \mathrm{kg}$, and vitamin C, $5 \mathrm{~g} / \mathrm{kg}$ fried potato chips. Both series of fortification experiments were conducted on the resulting fried chips from the four frying trials.

\section{Analytical methods:}

Determination of percentage oil of the fried chips: The determination of oil content absorbed in potato chips fried in every trial was conducted using Soxhlet apparatus for $16 \mathrm{~h}$ according to the AOCS (1998) methods.

Determination of the physical and chemical characteristics: The refractive index at $25^{\circ} \mathrm{C}$, smoke point, acid value and peroxide value were determined according to the AOCS (1998) methods.

Determination of the susceptibility to oxidation with the Rancimat method: Five grams of oils with antioxidants (TBHQ, retinyl palmitate, ascorbyl palmitate and tocopherol) and without any additives (control oil) were accurately weighed into each of the six reaction vessels, and the following procedure was carried out according to the method described by Tsakins et al. (1999). The Metrohm Rancimat 679 was switched on until the temperature of the oil batch reached $100^{\circ} \mathrm{C}$. Then $60 \mathrm{~mL}$ of distilled water was placed into each of the six conductivity cells, and the airflow was set at $20 \mathrm{~L} / \mathrm{h}$. The temperature was 
checked to ensure that it had a constant value. The air supply was connected to the tubes containing the oil samples, and the chart recorder was started. The determination continued automatically until conductivity reached its maximum value and the induction period was recorded.

Determination of foam height: The method of Fritsch et al. (1979) was used for the determination of the foam height of the abused oil, which could be summarized as follows: $40 \mathrm{~mL}$ of the oil sample were taken from the fryer daily and placed in a $100 \mathrm{~mL}$ glass beaker $(4.7 \mathrm{~cm}$ i.d.). The initial height of the oil was recorded. Potatoes were cut with a machine cutter to obtain similar size disks $\left(1 \times 1 \times 1 \mathrm{~cm}^{3}\right)$. Five potato disks were dropped into the beaker when the oil temperature was $180^{\circ} \mathrm{C}$. The maximum foam height in $\mathrm{cm}$ was observed and measured.

Determination of the changes in viscosity during frying: The changes in viscosity of oils during frying were determined using the Viscometer Brookfield RVDV-1+C/P (Cone/Plate Viscometer, CP-41) connected to a water bath Brookfield TC500. Viscosity was carried out at $25^{\circ} \mathrm{C} \pm 0.01^{\circ} \mathrm{C}$ according to the method described by Howard (1991).

Determination of conjugated acids: Conjugated triene was identified and determined in oils that were used in the frying processes according to the method described by the IUPAC (1992) using UV/Vis spectrophotometer Model Labomed, Inc. U.S.A at $268 \mathrm{~nm}$ for conjugated triene.

Determination of polymer content: The method of Pel-Fen and Nawar (1986) was used to determine polymers.

Determination of the thiobarbituric acid (TBA) value: The method of Sidwell et al. (1954) was followed to determine the absorbance of reactive substances to TBA at $530 \mathrm{~nm}$.

Extraction of oil from stored potatoes chips: The fried potato chips were removed from the oven at 24-hour intervals for 8 days to extract the absorbed oil. The chips $(200 \mathrm{~g})$ were ground in a waring blender and the absorbed oil was recovered in two successive extractions with $500 \mathrm{~mL}$ of petroleum ether, bp $40-60^{\circ} \mathrm{C}$, at room temperature over-night. The oil was separated from the chips by filtration with a sintered glass funnel. The filtrates were combined and the petroleum ether was removed under a vacuum, at $60^{\circ} \mathrm{C}$, with a rotary evaporator. The oil was subsequently left for $1 \mathrm{~h}$ in a vacuum oven, at $60^{\circ} \mathrm{C}$, for removal of residual solvent. The extracted oils were stored in a freezer until analysis.

Chemical assays of extracted oil from stored potatoes chips: The accelerated oxidative test was performed by determining the induction period (IP) of the oil sample using a Metrohm Rancimat Model 679 (Metrohm Herisau, Switzerland) according to the method described by Park et al. (2002). The peroxide value and absorbance at $268 \mathrm{~nm}$ (E268) were also measured to compare the oxidative stability of the extracted oil.

All analyses were conducted in duplicate and the results presented are the average of the obtained values.

\section{RESULTS AND DISCUSSION}

Although tocopherols are known to be the most important natural antioxidants in fats and oils, controversial findings of their effects have been determined in different model systems (Lampi and Piironen, 1998). Tocopherol was not used for frying in our study due to the drastic drop in the activity of tocopherol and degradation of the oxidative stability of tocopherol during deep fat frying which Gordon and Kourisma (1995), Holownia et al. (2001) and Park et al. (2002) reported. We therefore preferred to fortify the fried potato chips with tocopherol (vitamin E) after the frying process and before storing in the oven at $63^{\circ} \mathrm{C}$.

\section{Effect of antioxidants on the oxidative stability of palm olein}

The ability of oils to resist the oxidative rancidity at $100^{\circ} \mathrm{C}$ was measured using the Rancimat method. The calculated induction period (IP) (hours) is shown in Figure 1. Commercial olein oil had an induction period of $18.5 \mathrm{~h}$ and adding the synthetic antioxidant (TBHQ) increased its resistance to oxidation to almost twice its original value (32.17 h). Adding natural antioxidants (antioxidant vitamin) such as retinyl palmitate (RP, vitamin $A$ ), ascorbyl palmitate (AP, vitamin $\mathrm{C}$ ) and tocopherol (Toc, vitamin E) had almost the same effect and its resistance to oxidation increased $1.3,1.1$ and 1.2 of its original value, respectively. Similar results on TBHQ, AP, and Toc efficiency on the oxidative stability of oils was also reported by Gordon and Kourimska (1995). The low activity of the AP in the Rancimat test may be attributed to the rapid flow of oxygen, since AP acts as an antioxidant by removing oxygen, and hence is

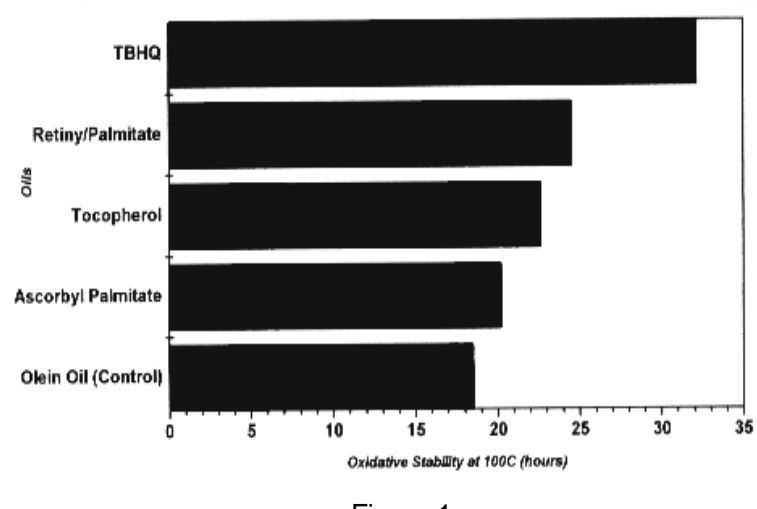

Figure 1

Effect of Adding Different Antioxidants on the Oxidative Stabulity (hours at $100 \mathrm{C}$ ) of Olein Oil. 


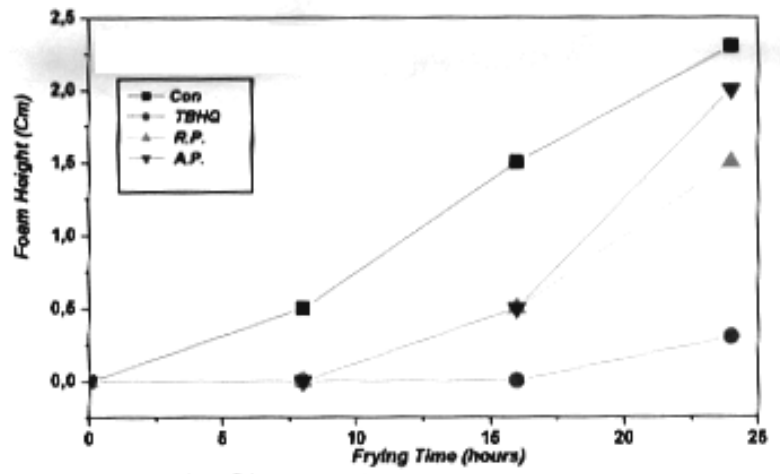

Figure 2

Changes in Refractive Index at 25C During Frying Time.

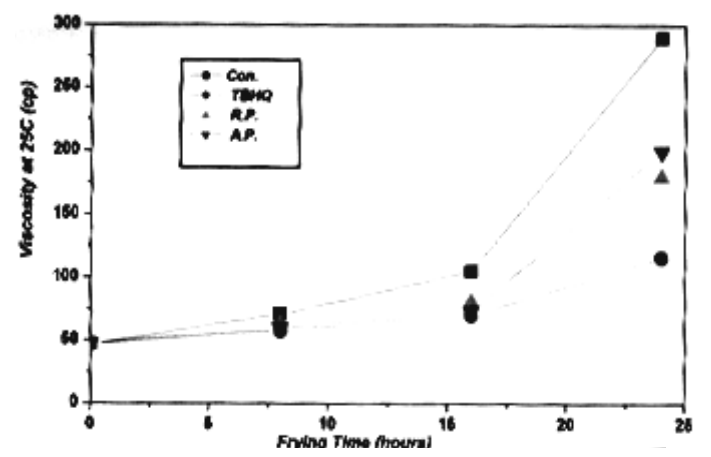

Figure 3

Changes in Viscosity at 25C (cp) During Frying Time.

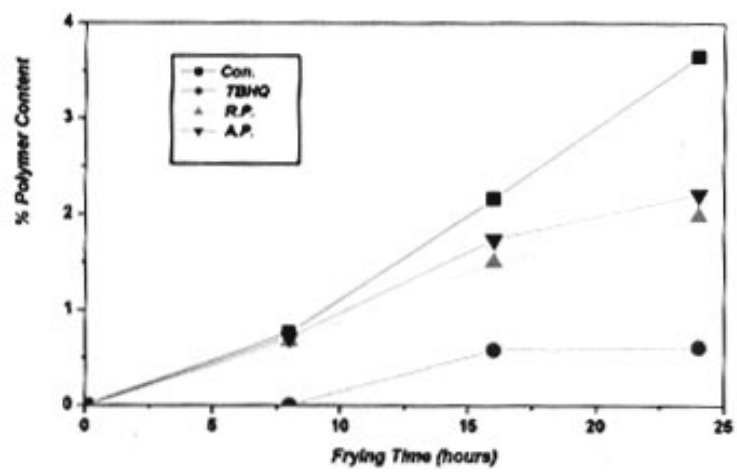

Figure 4

Changes in \% Polymer Content During Frying Time.

more active under conditions where oxygen is limited (Gordon and Kourimska, 1995).

\section{Changes in physicochemical properties of used oils}

Changes in physicochemical properties of used oils during frying potato chips at $180^{\circ} \mathrm{C}$ with or

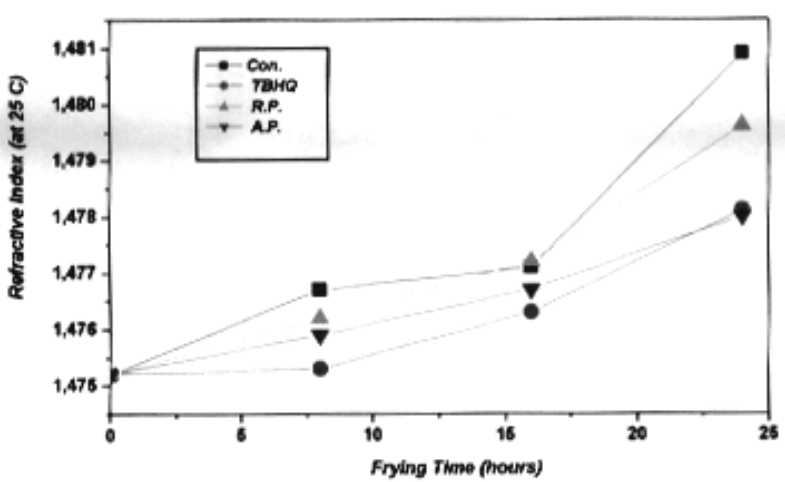

Figure 5

Changes in the Formation of Foam Height During Frying Time.

without added antioxidants were monitored by measuring the formation of high molecular weight compounds (polymers). They were observed by measuring the linear increase in the refractive index at $25^{\circ} \mathrm{C}(\mathrm{RI})$ (Figure 2), the progressive increase in viscosity (cp) at $25^{\circ} \mathrm{C}$ (Figure 3), and the increase in percentage of polymer materials (Figure 4) during the frying process. Because of these increments, there was an increase in foam tendency. Results in Figures 2, 3 and 4 showed a gradual increase in $\mathrm{RI}$, viscosity and percentage polymer materials in all samples. All of them followed the same trend but had different deteriorative levels. Palm olein without any additive (control) produced severe damage during potato frying at $180^{\circ} \mathrm{C}$, however, the addition of antioxidants either synthetic (TBHQ) or natural (RP, AP) improved its frying characteristics. The increment rate of polymer compound formation followed the same trend in the control oil and oils containing natural antioxidants (RP, AP) while adding TBHQ formed polymers after 8 hours of frying and hindered the formation of this compounds after 16 hours. Results in Figure 5 showed that the foam started to appear only after $8 \mathrm{~h}$ of frying using the control oil, then, there was a gradual increase in foaming tendency with the increase in frying hours. The foam took 24 or $16 \mathrm{~h}$ to begin to appear when TBHQ or natural antioxidants were used. TBHQ shows the best performance in protecting the oil from the thermo-oxidative deterioration during frying followed by RP and then AP that produces almost a similar effect as RP. Thermal and oxidative polymerization of oil during frying causes foam formation when moist foods are deep-fried which makes the fried product greasy and less crispy and loses consumer acceptability (Allam, 1994; Samah and Fyka, 2002; Fyka and Samah, 2003).

Because of thermal decomposition of oil during frying, free fatty acids (FFA) and other volatile and degradation oils leave the oil as gases and appear as smoke. The increase in FFA causes a considerable decrease in the smoke point of oils, resulting in a significant fire risk. For safety reasons, the 


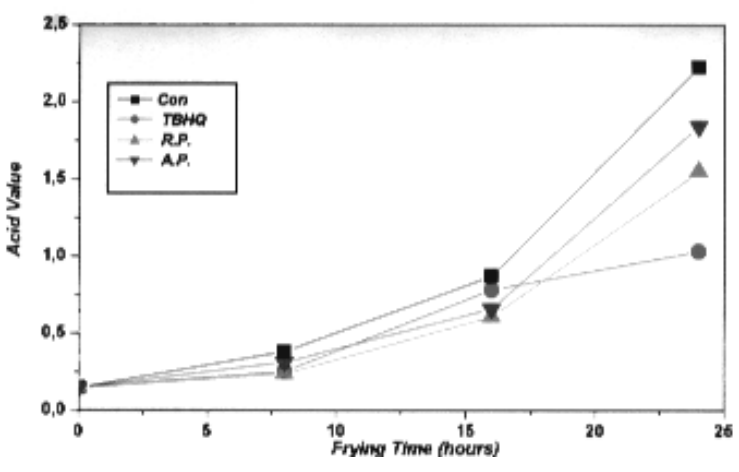

Figure 6

Changes in Acid Value During Frying Time.

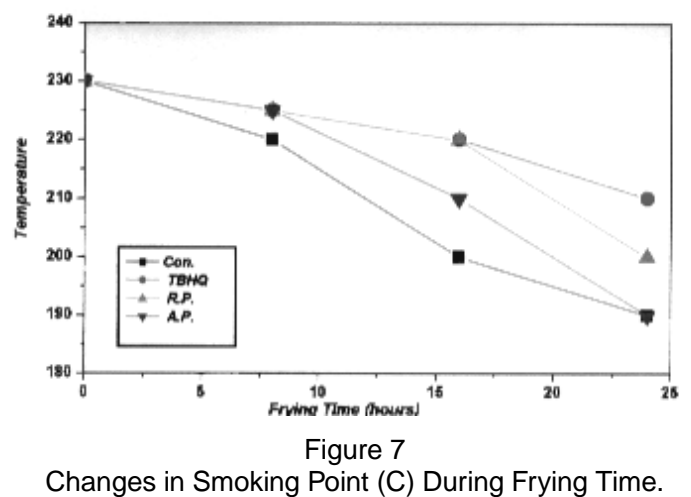

temperature of the frying oil should be kept below its smoking point (McSavage and Trevison, 2001).

The acid value gradually increased in all samples (Figure 6). The smoke point of the control oil decreased drastically during frying by about $10^{\circ} \mathrm{C}$ after $8 \mathrm{~h}$ of frying while it took $16 \mathrm{~h}$ of frying to reach this point using antioxidants (TBHQ, RP, and AP). The smoke point continued to decrease with the increase in frying hours. TBHQ showed the best protecting action against thermo-oxidative deterioration during the frying period, followed by RP and AP (Figure 7).

The formation of peroxide compounds, conjugated fatty acids and aldehyde compounds are shown in Figures 8, 9 and 10, respectively. The evolution of peroxide compound formation closely paralleled the formation of polymers. There was a sharp increase in peroxide value for the control oil after $8 \mathrm{~h}$ of frying followed by a slow rate of peroxide formation after $15 \mathrm{~h}$. This trend was also observed with the formation of aldehyde compounds and conjugated fatty acids (Figure 10). The increase in degradation compounds and conjugated fatty acids as a result of the frying condition was also observed by Houhoula et al. (2002), Samah and Fyka (2002), and Fyka and Samah (2003).

Ascorbyl palmitate (AP) protected deep fried potato chips from lipid peroxidation better than BHT did (Gwo et al., 1985) and was extremely effective at

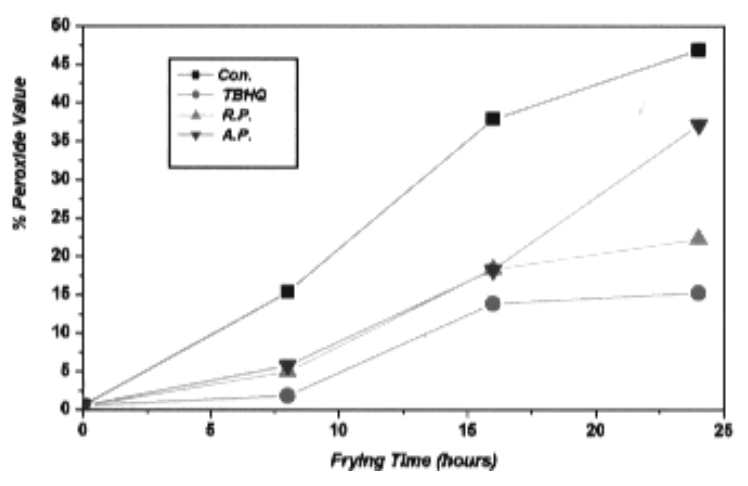

Figure 8

Changes in Peroxide Value During Frying Time.

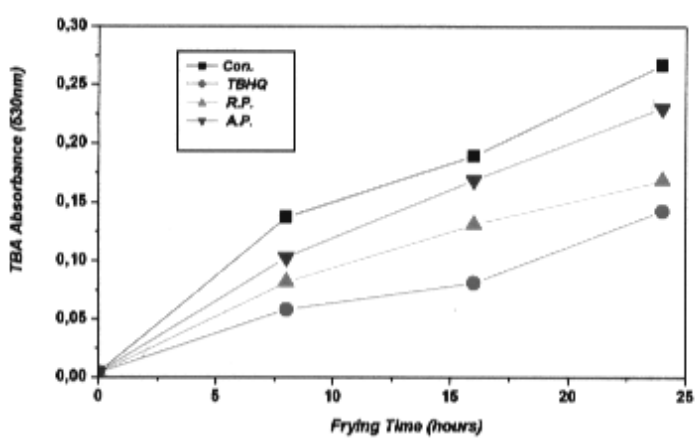

Figure 9

Changes in TBA Absorbance (530 nm) Foam Height During Frying Time.

minimizing the photosensitized oxidation of oils and its effectiveness was concentration dependent (Lee et al., 1997).

\section{IP changes of abused frying oils during frying periods}

The accelerated oxidative test was performed by determining the induction period (IP) of oil samples during the frying period. Results shown in Figure 11 revealed that frying with or without adding antioxidant decreased the oxidative stability of the

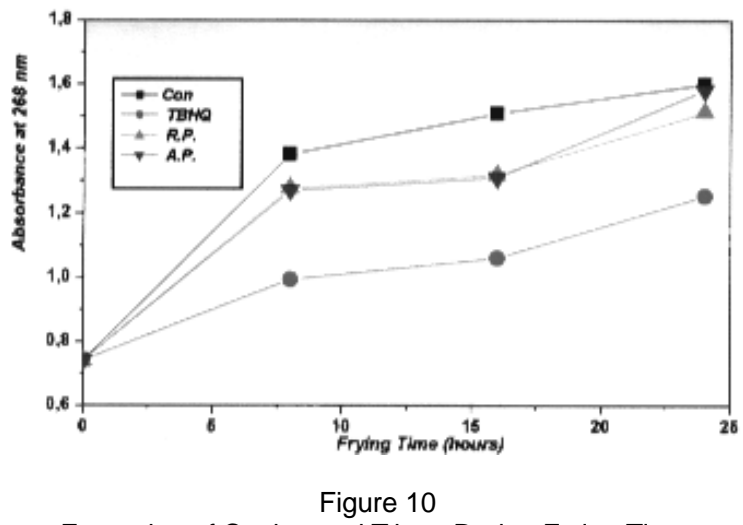

Formation of Conjugated Triene During Frying Time. 


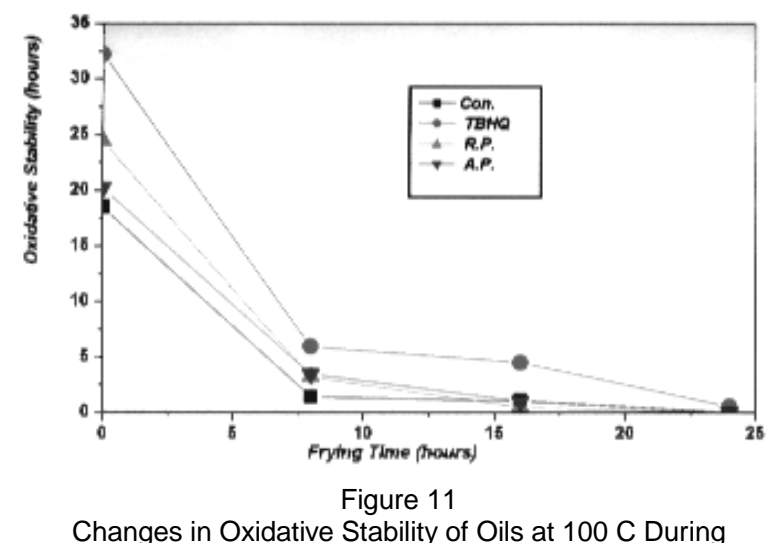

Changes in Oxidative Stability of Oils at $100 \mathrm{C}$ During Frying Time.

abused oils at $100^{\circ} \mathrm{C}$. The oxidative stability of the control sample at $100^{\circ} \mathrm{C}$ could not be determined after $16 \mathrm{~h}$ of frying because it was below $0.5 \mathrm{~h}$. Using TBHQ almost maintained its frying quality until the end of frying hours $(24 \mathrm{~h})$, while RP and AP maintained oil oxidative stability during $16 \mathrm{~h}$ of frying and collapsed after that.

\section{Extracted oil from stored fried potato chips}

The percentage of oil was determined in potato chips fried in each treatment. The oil content varied from $43.28,44.83,50.34$ and $54.14 \%$ of the chips' weight fried in oils containing TBHQ, RP, control oil, and AP, respectively. Fried chips from the individual trials containing approximately $0.008 \% \mathrm{TBHQ}$, $0.05 \%$ vitamin C (AP) and 0.04 vitamin A (RP) (as calculated from the percentage-absorbed oil during frying) showed better storage stability at $63^{\circ} \mathrm{C}$ and increased their storage ability in comparison to chips fried in oil with no additives.

The improvement of storage characteristics of fried chips was observed by measuring the IP at $100^{\circ} \mathrm{C}, \mathrm{PV}$ and conjugated triene content in oils extracted from the stored fried chips (Figures 12, 13 and 14 , respectively).

\section{IP changes of extracted oil from stored fried potatoes chips}

In Figure 12, the curves of IP obtained in the Rancimat method for fried products stored at $63^{\circ} \mathrm{C}$ for up to 8 days are presented. In the early stage, the IPs of oils extracted from chips fried in oils containing antioxidants, TBHQ, RP, and AP were 7.37, 8.33, and $15.60 \mathrm{~h}$, respectively and were higher than that of the control sample $(6.6 \mathrm{~h})$. This tendency continued as the storage period increased over time. The IPs of the control sample and samples fried in antioxidants were less stable than that of the samples fortified with vitamins $E$ and $C$ after frying. As shown in Figure 12 , the IPs of the control samples fried in antioxidant

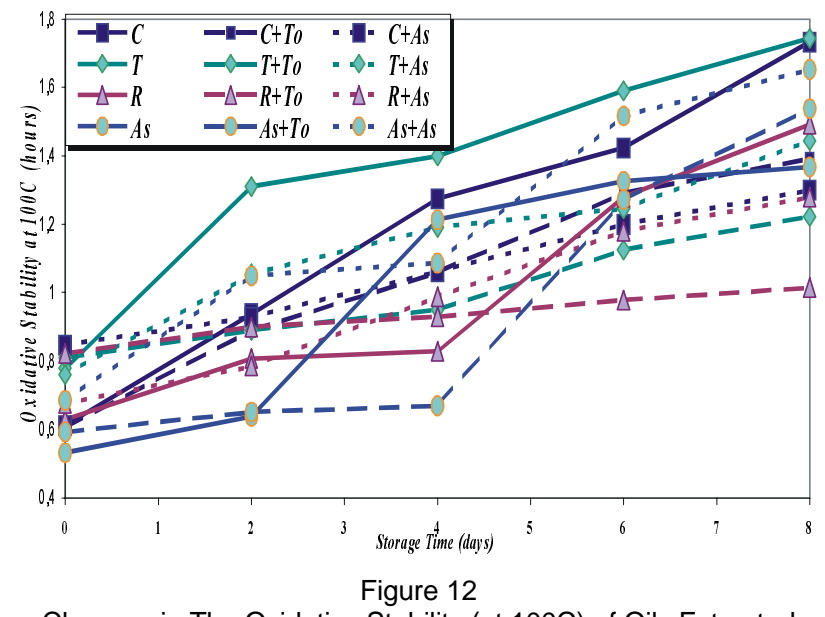

Changes in The Oxidative Stability (at 100C) of Oils Extracted from Fried Potatoes Chips During Storage Time.

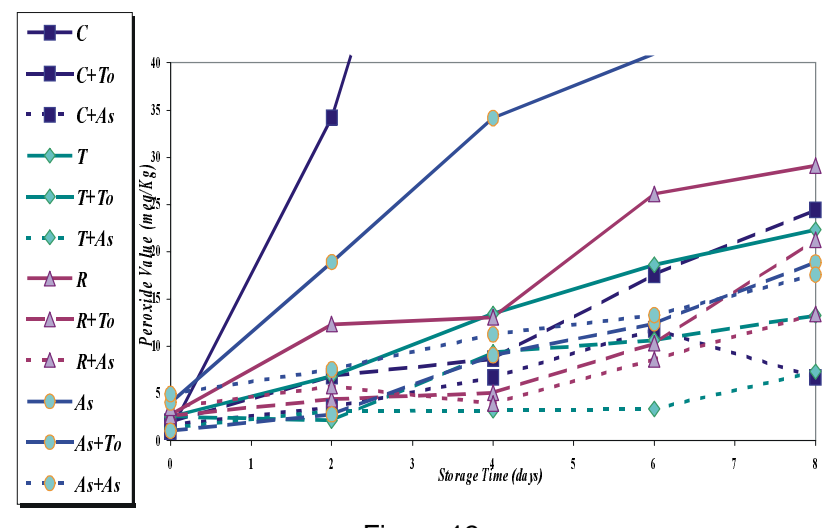

Figure 13

Changes in Peroxide Value of Oils Extracted from Fried Potatoes Chips During Storage time.

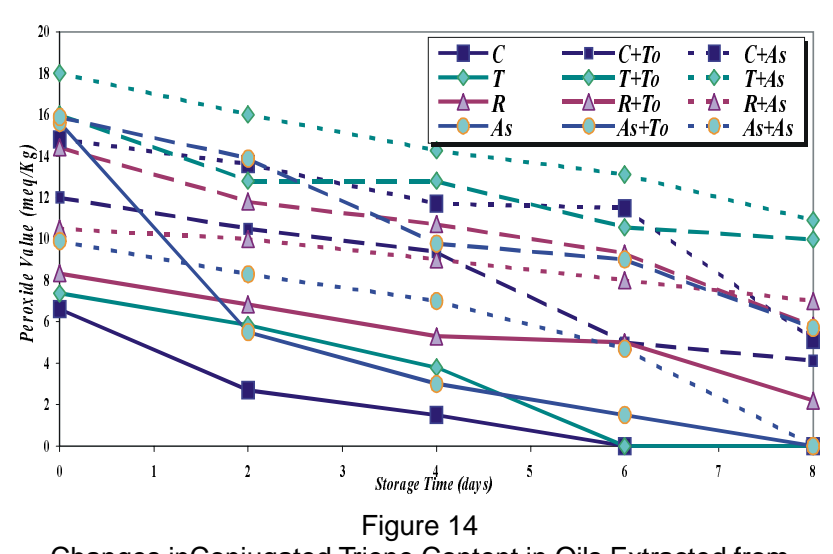

Changes inConjugated Triene Content in Oils Extracted from Fried Potatoes Chips During Storage time.

treatments decreased drastically in comparison to the fortified samples after frying. Fortification of potato chips after the frying procedure and before packing and storing at $63^{\circ} \mathrm{C}$ increased the oxidative stability of oils extracted from the stored chips during storage time. They were measured at zero time, 12, 
and $14.82 \mathrm{~h}$ for the control sample and fortified with Toc and AP, respectively; and were 16 and $18 \mathrm{~h}$ for samples fried in oil containing TBHQ and fortified with Toc and AP, respectively. This tendency also continued until the end of storage time. Moreover, after 4 days of storing control samples, after 6 days for samples fried with TBHQ, 8 days for samples fried with $A P$ and samples fried with $A P$ and fortified with vitamin $C$ (AP), the IPs of the extracted oils could not be measured as they were below $0.5 \mathrm{~h}$ indicating their detection limit. From the results of the Rancimat method shown in Figure 12, the antioxidants added to the oils before frying determined the oxidative stability and IP of oils extracted from potato chips stored for 8 days at $63^{\circ} \mathrm{C}$. Adding vitamins $\mathrm{E}$ and $\mathrm{C}$ after frying increased the IP of samples throughout storage time until the end of 8 days, suggesting that their antioxidant activity is strong. Therefore, IP measurement is possible to determine the stability of extracted oil from stored fried chips.

The increase in oxidative stability of the oils extracted from chips fried in oil containing TBHQ and fortified with Toc and AP suggested the role of polyphenolic compounds in protecting these vitamins $E$ and $C$ by supporting their antioxidant function during storage at $63^{\circ} \mathrm{C}$ for 8 days (Jacob, 1995).

\section{Peroxide value changes of extracted oil from stored fried potatoes chips}

Hydroperoxides initiate autoxidation of oil rancidity by absorbing oxygen and subsequently producing carbonyl compound by-products. Therefore, $\mathrm{PV}$ is used to express the oxidation level of the oil (Camire and Kantor, 1999). As shown in Figure 13, PV gradually increased for all treatments during storage time. The initial PV of each sample was slightly different and that may be attributed to the similar quality characteristics of all the tested frying oils during the first 8 hours of frying where the samples were collected. The increase in PV during the storage of fried and fortified potatoes followed the same trend as IP values (Figure 12) and E268 values (Figure 14).

The results in Figures 8 and 13 show significant differences between the values of peroxides forming during the frying period ( $24 \mathrm{~h}$ ) and during the storage period (8 days). Whereas the storage of oil at $63^{\circ} \mathrm{C}$ leads to an increase in peroxide value and the formation of conjugated triene, the use of oils for frying does not lead to high increases in peroxide value because hydroperoxides decompose spontaneously above $150^{\circ} \mathrm{C}$ (Gorden and Kourimska, 1995). Thus, the major changes in frying oils are the formation of polymers and lipid degradation products. Lower levels of hydroperoxides are formed during the cooling of oil after frying and this leads to an increase in PV after each frying operation and it was confirmed by removing samples from the frying oil and assessing their stability using the Rancimat method (Fig 11).

The results from Figure 11 show that $A P$ has been demonstrated to synergize TBHQ and tocopherol (Vicente et al., 1985).

Masson et al. (2002) reported that the addition of ascorbyl palmitate to the fried potatoes had a significant effect resulting in higher retention of natural antioxidants, higher induction time and lower $\mathrm{PV}$ at any storage time.

\section{Conjugated triene (E268) changes of extrac- ted oil from stored fried potato chips}

The changes in E268 followed the same trend as the formation of peroxide compounds (PV) (Figure 13). Figure 14 showed that, at zero time, E268 values varied between samples due to the different frying media: control without any additives, and frying with TBHQ, RP or AP. After storage at $63^{\circ} \mathrm{C}$, the effect of fortification with vitamin $E$ (Toc) was demonstrated by the low E268 values, which express the synergistic effect of vitamin $E$. The results in Figure 14 showed that samples fried in oil containing vitamins $A$ and $C$ had better storage ability and fortification with vitamin $E$ and increased the storage stability of fried potato chips, which demonstrates the vitamin E-sparing action of vitamin C (Vatassery et al., 1989).

The changes in IPs, PV and E268 values of the extracted oils from all the stored fried chips suggested that, there was a synergistic effect between AP and Toc and Han et al. (1991) observed this through the increase in the IP of stored fish oil.

Vitamin $\mathrm{C}$ can reduce the tocopheroxyl radical, thereby regenerating the active form of vitamin $E$ (or spare vitamin E) (Lee et al., 1997; Castellini et al., 2000 ). The later confirms the synergistic action of ascorbate with tocopherol and the benefit of using high levels of the two vitamins to prevent oxidative stress during rabbit meal processing and storage.

Changes in IPs, PV and E268 during the storage of fried products with or without added antioxidants were also examined by Lolos et al. (1999), Masson et al. (2002) and Park et al. (2002); they reported an increase in storage ability of the fried products with the addition of different antioxidants whether synthetic or natural .

Natural antioxidants have been proven effective in retarding peroxide formation in cottonseed and soybean oil absorbed in fried bread cubes, during storage of the cubes at $60^{\circ} \mathrm{C}$ as reported by Tian and White (1994). Fortification with natural antioxidants (culinary herbs) was used to inhibit lipid oxidation in raw and cooked minced meat patties during storage (Souzan et al., 1999). 
Ascorbyl palmitate (AP) was effective in promoting canola oil stability in oils subjected to accelerated storage at $65^{\circ} \mathrm{C}$ for up to 12 days (Schaal oven test) (McMullen et al., 1991) and preserved -tocopherol in sunflower oil at $95^{\circ} \mathrm{C}$ and delayed the onset of rancidity, both effects increasing with AP concentration (Beddows et al., 2001).

Accelerated storage stability at $65^{\circ} \mathrm{C}$ and monitoring the oil deterioration of stability by measuring PV has been used by several other researchers (Liang and Schwarzer, 1998; McMullen et al., 1991; Lolos et al., 1999; Park et al., 2002).

\section{CONCLUSION}

The control oil (without any additive) was much more affected by thermal oxidation and polymerization during the frying process demonstrated by the formation of degradation compounds. The addition of synthetic and natural antioxidants slowed its accelerated deterioration by decreasing the formation rate of conjugated fatty acids, peroxide compounds and retarded the formation of aldehyde and polymer compounds. The protective effect of antioxidants followed this order TBHQ $>$ RP > AP. Ascorbyl palmitate (vitamin C) has been proven an effective antioxidant under a range of conditions and acts synergistically with phenolic antioxidants including TBHQ and tocopherol. Vitamins A (RP), C (AP) and E (Toc) interact and complement each other. Similarly, polyphenolic compounds (TBHQ) also protect these vitamins by supporting their antioxidant function. Vitamin $\mathrm{C}$ has been shown to reinforce the antioxidant effect of vitamin $\mathrm{E}$.

Potato chips are consumed by a large sector of the population (children, youth and adults) all at an age in need of vitamins $(A, C, E)$ and contribute in providing these consumers with almost all the Recommended Daily Intake (RDI) of these vitamins. Data from the conducted storage test reveal that fortifying the chips with vitamins $A, C$ and $E$, either by frying in oil containing vitamins $A$ or $C$ or after frying by the two fortification methods (dipping in oil containing vitamin $\mathrm{E}$ or by dispersing vitamin $\mathrm{C}$ fine powder on the surface of the fried chips), not only enriched their nutritional value but also increased their storage ability.

\section{LIST OF SYMBOLS}

Con: Control Sample

TBHQ: Tertiary butylhydroquinone

RP: Retinyl palmitate

AP: Ascorbyl palmitate

C: Oil extracted from potato chips fried in control oil (control sample)

C+Toc: Oil extracted from control sample after dipping in oil containing tocopherol (Toc)

C+As: Oil extracted from control sample after sprayed with AP
$\mathrm{T}$ : Oil extracted from potato chips fried in oil containing TBHQ

T+Toc: Oil extracted from $T$ sample after dipping in oil containing Toc

$T+$ As: $\quad$ Oil extracted from $T$ sample after sprayed with AP

$R$ : Oil extracted from potato chips fried in oil containing RP

R+Toc: Oil extracted from $R$ sample after dipping in oil containing Toc

$R+A s:$ Oil extracted from $R$ sample after sprayed with AP

As: Oil extracted from potato chips fried in oil containing AP

As+ Toc: Oil extracted from As sample after dipping in oil containing Toc

As+As: Oil extracted from As sample after sprayed with AP

Note: Oil extracted from all samples (C, T, R, As) during storage period at $63^{\circ} \mathrm{C}$ in electric oven.

\section{REFERENCES}

Abdel-Rahman, M.K. 2001. Effect of feeding rats on thermally oxidized sunflower oil and antioxidants on their oxidases activity. Ph.D. Thesis, Fac. of Agric., Cairo Univ.

Allam, S.S.M. 1994. Preparation of high stable frying oils. Ms. Thesis, Fac. of Agric., Cairo Univ.

Allam, S.S.M., El-Sayed, F.E. 2002. Improving the Frying Characteristics of Cottonseed Oil by Blending with Apricot Kernel Oil. $4^{\text {th }}$ Food Quality Conf. COMIBASSAL, Alex. Egypt.

Allam, S.S.M., Mohamed, H.M.A. 2002. Antioxidative Efficiencies and Stability of Some Waste Materials from Selected Plants. La Rivista Italiana Delle Sostanze Grasse, LXXIX, 92 ${ }^{\text {nd }}$ Annual Meeting \& Expo, U.S.A.

Anon 1996. Roche Antioxidants. F-Hoffmann-La Roche Ltd, Vitamins and Fine Chemicals Division. $\mathrm{CH}-4002$ Basel (Switzerland)

A.O.C.S. 1998. Official methods and recommended practices of the American Oil Chemists' Society. 5th ed., American Oil Chemists' Society Press, Champaign, U.S.A.

Beddows, C.G., Jagait, C., Kelly, M.J. 2001. Effect of ascorbyl palmitate on the preservation of -tocopherol in sunflower oil, alone and with herb and spices. Food Chem. 73, 255-261.

Block, G., Langseth, L. 1994. Antioxidant vitamins and health prevention. Food Technol. 46, 80-83.

Byrd, S.J. 2001. Using antioxidants to increase shelf life of food products. Cereal Foods World, 48-53.

Camire, M.E., Kantor, M.A. 1999. Dietary supplements: nutritional and Ikegel considerations. Food Technol., 87-96.

Castellini, C., Dal Bosco, A., Bernardini, M. 2000. Improvement of lipid stability of rabbit meat by vitamin $\mathrm{E}$ and $\mathrm{C}$ administration. J. Sci. Food Agric. 81, 46-53.

Coben, H.A., Neuman, I., Nabum, H. 1997. Blocking effect of vitamin $\mathrm{C}$ in exercise-induced asthma. Arch. Pediatr. Adolesc. Med. 151, 367-370.

Drachman, D.A., Leber, P. 1997. Treatment of Alzheimer's disease-searching for a breakthrough, settling for less. [Editorial], N. Engl. J. Med. 336, 1245-1246. 
Elliott, J.G. 1999. Application of antioxidant vitamins in foods and beverages. Food Technol., 46-48.

El-Sayed, F.E., Allam, S.S.M. 2003. Thermoxidative and hydrolytic changes in oils used for frying the frozen pre-fried foods. J. Food Lipids 10, 285-300.

Evans, D.A., Morris, M.C. 1996. Is a randomized trial of antioxidants in primary prevention of Alzheimer disease warrantee? Alzheimer Assoc. Disord. 10, 45-49.

Farriol, M., Mourelle, M., Schwartz, S. 1994. Effect of vitamin $\mathrm{C}$ and vitamin $\mathrm{E}$ analogue on aged fibroblasts. Rev. Esp. Fisiol. 50, 253-257.

Fritsch, C.W., Edberg, D.C., Magnuson, F.S. 1979. Changes in dielectric constant as a measure of frying oil deterioration. J. Am. Oil Chem. Soc. 56, 746.

Gordon, M.H., Kourisma, L. 1995. The Effects of antioxidants on changes in oils during heating and deep-frying. J. Sci. Food Agric. 68, 347-353.

Gwo, Y.Y., Flick Jr, G.J., Dupuy, H.P. 1985. Effect of ascorbyl palmitate on the quality of frying fats for deep frying operations. J. Am. Oil Chem. Soc. 62, 1666-1671.

Han, D., Yi, O.S., Ship, H.K. 1991. Solubilization of vitamin $\mathrm{C}$ in fish oil and synergistic effect with vitamin $\mathrm{E}$ in retarding oxidation. J. Am. Oil Chem. Soc. $68,740-743$.

Hennekens, C.P.H. 1996. The Role of Antioxidant Vitamins in the Prevention of Cardiovascular Disease. Backgrounder, VNIS.

Hercberg, S., Galan, P., Preziosi, P., Alfarez, M., Vazquez, C. 1998. The potential role of antioxidant vitamins in preventing cardiovascular diseases. Cancer. Nutr. 14, 513-520.

Holownia, K.I., Erickson, M.C., Chinnan, M.S., Eitenmiller, R.R. 2001. Tocopherol losses in peanut oil during pressure frying of marinated chicken strips coated with edible films. Food Res. Int. 34, 77-80

Houhoula, D.P., Oreopoloulou, V., Tzia, C. 2002. A kinetic study of oil deterioration during frying and a comparison with heating. J. Am. Oil Chem. Soc. 79, 133-137.

Howard, D.W. 1991. A look at viscometry. Food Technol., $82-84$

I.U.P.A.C. 1992. Standard Methods for the Analysis of Oils and Fats and Derivatives, $7^{\text {th }}$ ed. International Union of Pure and Applied Chemistry. Pergamon Press, Oxford.

Jacob, R.A. 1995. The integrated antioxidant system. Nutr. Res. 15, 755-766.

Jacques, P.F., Tayler, A., Hankinson, S.E. 1997. Long-term vitamin $\mathrm{C}$ supplements use and prevalence of early age-related lens opacities. Am. J. Clin. Nutr. 66, 911-916.

Lampi, A.M., Piironen, V. 1998. $\alpha$ - and $\gamma$-Tocopherol as efficient antioxidants in butter oil triacylglycerols. Fett. Lipid 100, 292-295.

Lee, K.H., Jung, M.Y., Kim, S.Y. 1997. Quenching mechanism and kinetics of ascorbyl palmitate for the reduction of the photosensitized oxidation of oils. J. Am. Oil Chem. Soc. 74, 1053-1057.

Liang, C., Schwarzer, K. 1998. Comparison of four accelerated stability methods for lard and tallow with and without antioxidants. J. Am. Oil Chem. Soc. 75, 1441-1443.

Lolos, M., Oreopoulou, V., Tzia, C. 1999. Oxidative stability of potato chips: effect of frying oil type, temperature and antioxidants. J. Sci. Food Agric. 79, 1524-1528.

Masson, L., Robert, P., Dobarganes, M.C., Urra, C., Romero, N., Ortiz, J., Goicoechea, E., Perez, P., Salame, M., Torres, R. 2002. Stability of potato chip fried in vegetable oils with different degree of unsaturation. Effect of ascorbyl palmitate during storage. Grasas y Aceites 53, 190-198.

McMullen, L.M., Hawrysh, Z.J., Lin, C., Tokarska, B. 1991. Ascorbyl palmitate efficacy in enhancing the accelerated storage stability of canola oil. J. Food Sci. 56, 1651-1659.

Mc-Savage, J., Trevisan, S. 2001. Use and Abuse of Frying Oil. In: Culinary Arts and Sciences III, Editors: J.S.A. Edwards \& M.M. Hewedi, Cairo, Egypt.

Ocke, M.C., Krombout, D., Menotti, A. 1995. Average intake of antioxidant (pro) vitamins and subsequent cancer mortality in the 16 cohorts of the Seven Countries Study. Int. J. Cancer 61, 480-484.

Park, Y.S., Kim, Y.S., Shin, D.H. 2002. Antioxidative effects of ethanol extracts from rhus verniciflua stoke on yukwa (oil popped rice snack) base during storage. J. Food Sci. 67, 2474-2479.

Pel-Fen, W., Nawar, W.W. 1986. A technique for monitoring the quality of used frying oils. J. Am. Oil Chem. Soc. 63, 1363-1367.

Plotinick, G., Corretti, M., Vogel, R. 1997. Effect of antioxidant vitamins on the transient impairment of endothelium-dependent brachial artery vasoactivity following a single high-fat meal. JAMA 278, 1682-1686.

Salonen, J. T., Nyyssonen, K., Tuomainen, T.P. 1995. Increased risk of non-insulin dependent diabetes mellitus at low plasma vitamin $\mathrm{E}$ concentrations: a four-year follow up study in men. Br. Med. J. 311, 1124-1127.

Sidwell, C.G., Salwin, H., Benca, M., Mitchell, J.H. 1954 The use of thiobarbituric acid as a measure of fat oxidation. J. Am. Oil Chem. Soc. 31, 603-606.

Souzan, S.L., Lugasi, A., Hovari, J., Dworschak, E. 1999. Culinary herbs inhibit lipid oxidation in raw and cooked minced meat patties during storage. J. Sci. Food Agric. 79, 277-285.

Suknark, K., Lee, J., Eilenmiller, R.R., Phillipis, R.D. 2001. Stability of tocopherols and retinyl palmitate in snack extrudates. J. Food Sci. 66, 897-902.

Tian, L.L., White, P.J. 1994. Antipolymerization activity of oat extracts in soybean and cottonseed oils under frying conditions. J. Am. Oil Chem. Soc. 71, 1087-1094.

Tsakins, J., Lalas, S., Gergis, V., Dourtoglou, V., Spiliotis, V. 1999. Characterization of moringa oleifera variety mbololo seed oil of Kenya. J. Agric. Food Chem. 47, 4495-4499.

Tsakins, J., Lalas, S., Protopapa, E. 2002. Effectiveness of the antioxidants BHA and BHT in selected vegetable oils during intermittent heating. Grasas y Aceites 53 199-205.

Vatassery, G.T., Smith, W.E., Quach, H.T. 1989. Ascorbic acid, glutathione and synthetic antioxidants prevent the oxidation of vitamin $\mathrm{E}$ in platelets. Lipids $\mathbf{2 4}$, 1043-1047.

Velasco, J., Dobarganes, M.C., Marquez-Ruiz, G. 2002. Lipid oxidation in heterophasic lipid systems: oil-in-water emulsions. Grasas y Aceites 53, 239-247.

Vicente, T.S., Waysek, E.H., Cort, W.H. 1985. Determination of ascorbyl palmitate by high performance liquid chromatography. J. Am. Oil Chem. Soc. 62, 745-747.

Yanishlieva, N.V., Marinova, E.M., Marckov, I.N., Gordon, M.H. 1997. Effect of an ethanol extract from summer savory (saturejae hortensis I) on the stability of sunflower oil at frying temperature. J. Sci. Food Agric. 74, 524-530. 